\title{
ISLAMIC PERSPECTIVE OF HUMAN BEING CHARACTERISTICS IN WILLIAM BLAKE'S POEMS
}

\author{
Wahyu Tejo Mulyo[1], Muzakki Afifuddin[2], Widyastuti Purbani[3]
}

\author{
[1]wahyutejo7@gmail.com, [2]muzakki@uin-malang.ac.id, [3]purbani@uny.ac.id \\ [1]Post-graduate Program of English Education, Yogyakarta State University, [2]Faculty of \\ Humanities, UIN Maulana Malik Ibrahim, Malang, [3]Post-graduate Program, Yogyakarta State \\ University \\ [1] [3]Yogyakarta, Daerah Istimewa Yogyakarta, Indonesia, [1]Malang, East Java, Indonesia
}

\begin{abstract}
This paper attempts to discover the characteristics of the human being through William Blake's Poems as an alternative definition. Among Blake's poems, The Divine Image and The Human Abstract are the most representative of discovering human characteristics. Moreover, this study strives to establish the correlation between Islamic values and European literature. The study uses new criticism in discovering the characteristics in the poems by two steps of analysis; paraphrasing and explication. After conducting the analysis, it is found that there are four positive characteristics in The Divine Image and four negative characteristics in The Human Abstract. The positive characteristics consist of mercy, pity, peace, and love, while the negative ones are exploitation, cruelty, conflict, and hypocritical humility. An Islamic expert, Murtadha Muthahhari, perceives the result of the analysis of the poem. Muthahhari explains fourteen positive and eight negative points of humans following the Holy Qur'an. It is found that the poems' human positive and negative characteristics include in MurtadhaMuthahhari's points of thought. Thus, the ideas of human being's characteristics in the poems are related to Murtadha Muthahhari's thoughts.
\end{abstract}

Keywords: human being characteristics, Islamic perspective, William Blake’s poems

\section{INTRODUCTION}

Religion is an emerging issue in the modern era and forms the backbone of most literary works (Eskandari, 2020; Amalia, 2020; Chile \& Crawford, 2021). It is defined as a personal set of an institutionalized religions, attitudes, beliefs, and practices (Victor and Treschuk, 2019). Religious values are obedience to religious doctrine, tolerance among religions, and harmony among religious communities (Turahmat et al., 2018). Religion values in literary works play an essential role. They can build people's character and raise education quality. The purpose of education is to develop the potential of students to become people who have faith and devotion to God Almighty, have a good character, be healthy, have the knowledge, be capable, be creative, be independent and be citizens who are democratic and responsible (Halimah and Nizan, 2017, and Sander, 2020). It plays a vital role in helping mental development for children physically and emotionally (Huda et al., 2017; Idris et al., 2018; Rothman \& Coyle, 2018). Religion as a part of culture solely possesses a relation with literature when the literary work is created in a particular culture and religion. Literature has been a mirror to society since time immemorial, and therefore it is no surprise that the echoes of such social, religious and cultural practices can be felt in the literary works (Thomas and Kumar, 2020, Je Weng, 2019). Literary work can convey higher or greater values and the meaning and nature of life (Arniati, Atmaja, and Pradana, 2020). For instance, Arab literature reflects Islamic spirituality due to Islam's Arabs' faith (Manshur, 2011:2). Faith is often associated 
with religion and relates to the relationship with God (Victor and Treschuk, 2019 and Anis \& Hasan, 2020).

Furthermore, Islam was not eagerly associated with other literary varieties of European literature due to the racial, political, and cultural differences (Robinson, 2007:5 and Madiou, 2020). Hence, it causes discrepancy toward Islam and European literature. Therefore, this research attempts to observe the human characteristics in English poems, written by a remarkable European poet, William Blake, through Islamic values. As a creature with finite capacity, the human being tries to connect him/herself with the absolute because, in a sense, he/she is capable of justifying his existence within this tremendous and unlimited universe (Oroskhan, 2021). Islam and European literature have always been separated due to racial, political, and cultural differences (Robinson, 2007:5). Thus, this study strives to establish the correlation between Islamic values and European literature. As a result, it can break down the border between European literature and Islam.

One of the literary works which have hidden meaning and full of messages is Poetry. Poetry is rich in the worthy meaning of each word (Nurgiyantoro, 2010). Thus, the research objects are William Blake's poems, The Divine Image (1789) and The Human Abstract (1794), which possess metaphysical and philosophical meaning about the characteristics of the human being. William Blake's poems were remarkable literary works in the Romantic Period. The majority of the works, in Songs of Innocent and Songs of Experience (etched in 1789 and 1794) poetry anthology, depicts a philosophical value about human being's characteristics as well(Abrams et al., 2001:1349. Among Blake's poems, The Divine Image in Songs of Innocent and The Human Abstract in Songs of Experience are believed as the representatives for discovering human being's characteristics (Abrams et al., 2001:1362). Unlike other Romantic period poets, Blake reveals the human being's characteristics of both positive and negative sides obviously and deeply. Moreover, to discover the semantic meaning in William Blake's The Divine Image and The Human Abstract, this research is conducted with New Criticism.
Concerning literary work in poetry, new criticism is a fair criticism to reveal the meaning of poetry, primarily philosophical poetry. Poetry is considered by many as the record and living conscience of societies documenting achievements, celebrations, history, and emotions expressing feelings and struggles (Salah, 2018). An often-noted anomaly of English in postwar US universities is the continuing influence of New Criticism long after its intellectual demise in the 1940s (Stewart, 2017). New criticism is particularly admired metaphysical poetry and regarded most highly forms of poetry in which irony, tension, paradox, and ambiguity interact with the semantics of the language (Newton, 1990, p. 39). New criticism was recognized for its emphasis on reading the interior and formal possessions of the literary manuscript.

On the other hand, the authors related to it had sumptuous philosophies on morality in poetry and poem (Khosravishakib, 2017). The principles of the new criticism are verbal. That is, literature is conceived to be a special kind of language whose attributes are defined by a systematic opposition to the language of science and of practical and logical discourse, and the explicative procedure is to analyze the meaning and interactions of words, the figure of speech, and symbols (Saraswati, 2019).

Concerning human characteristics, it is complex in defining human characteristics since each scholar has a varied definition. Gazalba (1978, pp. 20-21) describes that humans have two specifications; physical and spiritual. In contrast, Descartes believes that human is a spirit that utilizes physical form as a tool (Sanadji, 1985, p. 53). Furthermore, from an Islamic point of view, Syamsu (1983, p. 12), based on Holy Qur'an, believes that an-Naas (human) belongs to Allah SWT regarding their destiny in this world and hear after. The various and abstract definitions about human characteristics above indicate that defining human characteristics is peculiarly complex. The complexity of defining human characteristics encourages the researcher to redefine, more specifically, through The Human Abstract and The Divine Image by William Blake, a poet from London.

Furthermore, the researcher chooses MurtadhaMuthahhari as a representative among Islamic scholars in defining human being characteristics. The researcher believes 
that Muthahhari can represent Islamic thoughts because his thought about human being is based on Holy Qur'an as the primary Islamic reference. Muthahhari was born on February 2, 1919, from a pious family in Khurasan, Iran (Muthahhari, 2007:12) and passed away on May 2, 1979, and Ayatullah Khomeini declared that on May 3, 1979, became national jubilee to remember him. His voices and compositions are still valuable and learned by today's scholars. MurtadhaMuthahhari puts a big concern in defining human characteristics. Muthahhari elaborates clearly and precisely the human being characteristics, both positive and negative, regarding Islamic belief or primary source (Al-Qur'an) rather than other Islamic scholars. Thus, the researcher chooses MurtadhaMuthahhari as an Islamic scholar representative to provide a vivid definition of human characteristics perceiving William Blake's The Divine Image and The Human Abstract. The analysis is intensely significant regarding Islamic thought development. Hence, this study would contribute to the development of Islamic Civilization and Literary Study.

Based on the background above, this study formulates two problems: (1) What are the characteristics of the human being in William Blake's poems, The Divine Image and The Human Abstract? Furthermore, (2) What are the human being's characteristics in William Blake's poems perceived through Islamic perspective?

\section{ANALYSIS}

\section{Analysis of The Divine Image}

The Divine Image is included in an anthology poem titled The Song of innocence written by William Blake. Mainly for The Divine Image, Blakeexposes the positive traits of the human being. Blake begins the first line with the introduction of the main symbols of the poem. In this line, Blake portrays divine characteristics of Kindness (Mercy), Sympathy (Pity), Freedom (Peace), and Affection (Love).

\section{Mercy}

Mercy is a kindness or forgiveness shown to somebody you have the power to punish (Oxford Advanced Learner's Dictionary). It is also compassionate or kindly forbearance toward an offender, an enemy, or another person in one's power; compassion, pity, or benevolence (dictionary.reference.com/dfr.).

Mercy characteristic is noticed implicitly

in the third and fourth lines below.

To Mercy, Pity, and Love,

All pray in their distress,

And to these virtues of delight

Return their thankfulness. (ll. 3-4)

In these last two lines, there is a personification. The phrase 'these virtues of delight' refers to four divine characteristics (Mercy, Pity, Peace, and Love). A verb 'return' in the second line indicates that the subject of 'these virtues of delight' is an animate thing that can return something toward something. This subject seems to have hands that can return with the tool of hands. Moreover, the pronoun 'their' refers to the miserable people. These two lines mean that the miserable or unlucky people are thankful to God for His kindness which then 'the virtues of delight' (God) return their thankfulness. Due to the characteristic of Mercy, God blesses the miserable people through other people or humans who possess the same characteristic of mercy. Here, Blake emphasizes that those characteristics are hoped by people in difficult situations (sorrow, famine, and others) that they and other sympathetic people pray for the coming of divine characteristics above. Presumably, their prayers are accepted, and the divine goodness is applied by the human who has those characteristics. That good human shows their kindness, sympathy, freedom, and affection to the distressful people. The people are thankful to God for the goodness they have received. As a result, $\mathrm{He}$ keeps and increases His Kindness, Sympathy, Freedom, and Affection to the unlucky people who are thankful by sending them good human who is kind, sympathetic, peaceful, and having affectionate human.

The characteristic of mercy is also shown explicitly in the ninth line.

For mercy has a human heart, (1. 9)

The personification here is shown by using a characteristic of 'Mercy' that possesses ownership like a human, followed by a verb 'has.' Hence, this line means that a Divine Characteristic of Mercy also lies in and is possessed by humans. Moreover, a symbol exists in this line. 'Heart' is a symbol and connotation of something vital. The heart is one of the significant organs in the human body 
that pumps blood throughout the body. In other words, mercy is one of the fundamental characteristics of humans.

\section{Pity}

Pity is a feeling of sympathy and sadness for the sufferings or troubles of others. In other words, sympathetic or kindly sorrow is evoked by the suffering, distress, or misfortune, often leading one to give relief or aid or show mercy.

A characteristic of pity is shown implicitly in the second line below.

All pray in their distress, (1. 2)

This line shows a noble meaning but no figure of speech. The phrase refers to four Divine Human Characteristics that deserved to be praised for people who suffer sorrow. In addition, the pronoun in 'their distress' refers to the people who suffer pain or sorrow due to cruelty, for instance, people in Palestine and the famine of African people. The prayers are raised due to a sympathetic feeling of lucky people who live in a peaceful and comfortable place. Therefore, this line belongs to a characteristic of pity.

Another line that belongs to this characteristic is in the tenth line, explicitly shown with a personification.

Pity, a human face, (1.10)

Regarding the ninth line, if this line is paraphrased, it becomes pity has a human face. 'Pity' is personified as the human who has the authority of ownership. However, this line might likely emphasize that 'human face' is a part of 'Pity.' In other words, human also possesses a Divine Characteristic of Pity. Moreover, 'Face' refers to sympathy since it can express human feelings. The face is placed in the front head that the eyes, nose, and mouth are. It means that the face is also one of the significant parts of the human body. Therefore, this line emphasizes that pity is a significant characteristic that a human must own.

\section{Peace}

Peace is a situation or a time in which there is no war or violence in a country. Generally, peace could be defined as a state of mutual harmony between people or groups, especially in personal relations, and as the normal freedom from civil commotion and violence of a community; public order and security.
A characteristic of peace is not shown implicitly but explicitly in the fourth line.

And peace, the human dress. (1.12)

As in previous lines, the paraphrased sentence of this line becomes, and peace has the human dress. Similarly, it is a personification of a subject 'Peace' that can possess something humans do. Moreover, the symbol is also discovered in this line: the symbol of the human dress. Human dress symbolizes protection. Humans wear the human dress to protect the body (skin) from insects, ultraviolet light, and others that harm human skin. Dress is generally worn entirely on the body. Hence, the peace characteristic of humanity can protect them from cruelty or oppression that causes distress, sorrow, and massive death, making humans live in harmony.

\section{Love}

Love is a strong feeling of deep affection for somebody or something (oxf.). Love could also be defined as a feeling of warm personal attachment or deep affection for a parent, child, or friend (dfr.).

Similar to a characteristic of Mercy, Pity, and Peace, Love is delivered explicitly in the third eleventh, seventeenth and eighteenth lines.

And love, the human form divine,(1. 11)

The author presumably rearranges the grammatical structure to produce harmonic ending rhyme with the ninth line. Thus, the correct structure that does not change the meaning probably is - in a paraphrased form And love has the divine form of human due to the word 'divine' is an adjective that means 'Godlike' (oxf.). The personification of 'Love' here is shown as a living creature like a human who owns something. 'The human form divine' belongs to the divine characteristic of 'Love.' Since it is a part of 'Love, 'humans will have this divine characteristic and be a divine form if they also possess the characteristic and attempt to apply it daily life. Hence, this line means that love's characteristic lies in human form or behavior, which leads humans to be divine. In addition, from the similar form of lines in this third stanza, the speaker successfully portrays how significant the divine characteristics for humans are to possess.

And all must love the human form, In heathen, Turk, or Jew. (ll. 17-18) 
Characteristic of Love is also shown in these lines. The word 'all' refers to all people, and the phrase 'human form' refers to humans whose belief is 'heathen, Turk, or Jew.' However, these three believers (heathen, Turk, or Jew) denote all believers in the world. In other words, all people must love people who have particular beliefs. As a result of having a characteristic of love by so-called 'divine-human,' they are must be loved by other people.

\section{Mercy, Pity, Peace, and Love (all at once)}

Some lines are showing all characteristics at once in each line. The lines are in the fifth and sixth line, the seventh and eighth line, the fifteenth and sixteenth line, and the nineteenth and twentieth line.

For Mercy, Pity, Peace, and Love,

Is God, our father dear:(1. 5-6)

All four characteristics above belong to God, and it is only Him who has these characteristics. God in this poem is known as the Great Father (the Christians' belief: The First Epistle of St. John the Apostle, Chapter 5, 20).

And Mercy, Pity, Peace, and Love,

Is Man, his child, and care. (1. 7-8)

Unlike the two lines above, these lines show that four characteristics of Mercy, Pity, Peace, and Love, do not only belong to God but also a Chosen Man or a Son of God whom He cares (The Holy Gospel of Jesus Christ, According to St. Matthew, Chapter 26, 63-64).

Prays to the human form divine,

Love, Mercy, Pity, Peace. (1. 15-16)

The prayers are due to 'human's divine form.' This phrase is a synecdoche of the Son of God and Divine Human (People who possess four Divine Characteristics) who become a hope of distressful humans.

Where Mercy, Love, \& Pity dwell

There God is dwelling too. (1. 19-20)

A verb of ' $d$ well' in the first line above indicates that the inanimate things (the characteristic of Mercy, Love, and Pity) can move and decide what to do - in this line is an ability to gather and meet. Moreover, the characteristic of 'Mercy, Love, and Pity' symbolizes the divinehuman. Thus, these lines mean that God will also be with God when people or humans have these characteristics because those characteristics possessed by humans naturally belong to God. The human with those characteristics is only the reflection of God's characteristics. This God's characteristics are the same as the Islamic concept of God.

\section{Analysis of The Human Abstract}

As the opposite poem of The Divine Image, Blake tends to produce the negative traits of humans in this poem. He begins the poem with paradoxical lines in the first stanza. A feeling of sympathy will never occur if40selfish people do not make other people (especially nonexperts) encounter poverty and famine. Exploitation plays a significant role in causing poverty. The minority of egotists possess farmland and production tools (industry) that people in the majority need for daily fulfillment. In order to increase the wealth, the egotists employ the people in majority to be employees in producing the products in the industries or farmlands and pay a tiny amount of salary for them whereas it is necessary for them to fulfill the considerable amount of need every day that they can not fulfill by the salary. Hence, the practice of oppression conducted by the employers(egotists) causes the poverty of the oppressed people. As a result, the other kind of humans pities them (the oppressed people) who live unprosperously. A characteristic of kindness or forgiveness will not be possessed by humankind if no object or other human is taken pity due to their unhappiness. The cruel people conduct cruelty to other humans for their business and benefits. The distressed humans encounter pain and sorrow, even famine, homelessness, joblessness, and others. The other kind of humanity must pity those who suffer and cannot enjoy pleasure, comfort, and good living as the lucky people own.

\section{Exploitation}

Generally, exploitation is the use of somebody or something, often in an unfair way (oxf.). From another point of view, it is also believed as a selfish utilization (dfr.).

'Exploitation' is shown implicitly in the first and second line and also in the sixth line.

Pity would be no more,

If we did not make somebody Poor;(1. 1-2)

A figure of speech of paradox exists in these lines. The analysis begins with the word 'Pity' and 'Poor.' These words are characteristics that function as a noun (for pity) and adjective (for Poor). However, Blake uses a word 'Pity' and 'Poor' to refer all people who 
have a characteristic of pity and unlucky people who encounter poor conditions. Moreover, these lines display a contradictory phenomenon in which pity will not exist if people do not create other people's Poor. Thus, these lines show a paradoxical situation in which the paradox is related to the cause-andeffect condition that, in other words, the lines explain that 'there will be feelings of pity if cruel people conduct exploitation that causes poverty.

Furthermore, the two lines above explained the process of people having a feeling of pity. Rich human conduct exploitation toward people who need workplaces and money. The exploited people suffer from poverty. As a result of poverty, a pity characteristic occurs of people who live in prosperous conditions (including the author since he uses the pronoun ' $w e^{\prime}$ ' in the second line). This statement is related to Karl Marx's theory about poverty (1818-1883). Marx elaborated that the cause of poverty is exploitation (Exploitation Poverty, blame the employers, 2015).

Hence, the lines which show poverty above are included in a human characteristic of exploitation.

Till the selfish loves increase;(1. 6)

A paradox and personification exist in this line. A verbal paradox is shown by the contradictory phrase 'selfish loves.' Selfish is a negative characteristic that means thinking mainly of yourself and your own needs, not others, while love is a positive characteristic meaning a strong feeling of deep affection for somebody or something (oxf.). Moreover, 'selfish loves' produces a personification that seems like an animate creature that can reproduce becoming increased in numbers. However, the phrase is a characteristic that lies on humans and can not possess characteristics like humans. The characteristic of exploitation is also shown in one line above.

Additionally, selfish love can be defined as a feeling of love or likes to think about one's advantages than others. In other words, the human who has the feeling of selfish loves tends to increase their wealth and benefits, although it will suffer pain and sorrow for other humans. The definition of selfish love is related to the definition of exploitation explained above. Both selfish loves and exploitation have the same aim, to gain a considerable amount of one's benefit.

\section{The Analysis of Figure of Speech Cruelty}

Cruelty is a common term for a harmful practice. The negative practice is behavior that causes pain and suffering to others (oxf.). In short, cruelty is a cruel disposition or conduct (dfr.).

A characteristic of cruelty is shown many times in the poem, both implicitly and explicitly.

And mercy no more could be,

If all were as happy as we;(ll. 3-4)

These lines contain two figures of speech (simile and paradox) and imagery. The simile is discovered in the fourth line for displaying a comparative degree of '...as....as...'. It means that the distressful people have the same feeling of happiness as the lucky people. The paradoxical situation is displayed in these lines due to the cause-and-effect situation that, in other words, it means 'people feel merciful if cruel people (including the author noticed by a pronoun ' $w e$ ' in the fourth line) conduct cruelty to the innocent people. In terms of imagery, the word 'happy' shows that this line produces imagery of internal sensation since the lucky people presumably feel comfortable for their prosperous condition. The two lines above indicate a characteristic of cruelty. The paraphrased sentence of the lines is 'people will never feel merciful to others if they do not make them suffer pain and sorrow.' The process of mercy, related to these lines, is cruel human conduct cruelty to other humans. The weak human suffers pain and sorrow. At last, lucky human shows their kindness or mercy to those suffering people. In other words, the cause of pain and sorrow is cruelty conducted by a human.

\section{Then cruelty knits a snare, (1.7)}

Unlike other lines of cruelty, this line shows the characteristic explicitly. 'Cruelty' is personified as an animate creature. It seems like the cruelty possesses hands like a human that it can build traps for the prey. Moreover, a metaphor meaning in this line is produced by the word 'snare.' 'Snare' in this line does not mean a trap for an animal made from a rope (oxf.) but more metaphorically as a trap made by cruel people for innocent.

He sits down with holy fears, 
And waters the ground with tears;(1l. 9-

10)

Two lines above produce two figurative speech: paradox and symbol and imagery of internal sensation. The paradoxical situation is shown by each line, while a symbol is displayed by the plural word 'tears' in the tenth line. Every line above displays a paradox in which one case contradicts the other. The first line displays that 'the cruel people' are excitedly enjoying the rewards of cruelty they have conducted, but at the same time, innocent people who have been their victims are frightened of their sorrow and miserable conditions. Meanwhile, the paradox of the other line is between a verb 'waters' and a noun 'tears.' Commonly, a verb of water is associated with watering the dried plants to make them fresh. In other words, water is a positive activity that remains beneficial and advantageous or positive result for the plants. However, 'tears' are a symbol of distress and sorrow as an effect of cruelty. Thus, this line implies that cruel people tend to create distressful conditions toward innocent people that make them miserable and sad. In term of the imagery, a plural word 'fears' produce internal sensation imagery since the innocent people feel afraid of the miserable condition.

And the Raven his nest has made

In its thickest shade. (ll. 19-20)

Before understanding the intrinsic elements of these lines, the nineteenth line should be paraphrased due to its unorderly grammar. A paraphrase of the line is 'And the Raven has made his nest.' Blake writes this line intentionally to create the harmonic rhyme with the following line (twentieth line). In an account with the intrinsic elements, a figure of speech of symbol is vividly displayed in these two lines that are in a word of 'Raven' and 'thickest shade.' Moreover, the imagery produced is visual. The main subject in these lines is 'Raven.' According to Oxford Advanced Learner's Dictionary, the raven is a large black bird like a crow. From a general point of view, the raven is genuinely the giant bird in the crow family. However, the raven is well-known due to its mystical symbol.

The quote above explains that Raven tends to trick other animals, even his tribes, solely to make his stomach full (Eldrbarry in Raven in Mythology, 1998). Raven will even murder their tribes to eat their carcass, only to satisfy his appetite. Therefore, in this poem, Raven symbolizes cruelty - a cruel human who commits cruelty to other people intentionally. However, 'thickest shade' is a symbol of hypocrisy which almost cannot be revealed by the victims of the cruelty. Hence, the two lines above show that the cruel human is started to spread cruelty and conquer the world under the protection of hypocrisy (thickest shade). Additionally, the visual imagery lies in the whole lines above that reader might consider that 'Raven has made his nest in its thickest shade' through a visual sense.

\section{Conflict}

Conflict is a state of struggle, fight, or serious disagreement (oxf.). In other words, it is in the form of controversy or quarrel (dfr.).

Only the fifth line shows the characteristic of 'Conflict' in the poem.

And mutual fear brings peace, (1. 5)

There are two figures of speech in this line: personification and paradox. The paradox is shown in the whole line, while personification is in the phrase 'mutual fear.' The phrase is portrayed as having hands like a human that can bring something (in this line is carrying 'peace'). In terms of paradox, it is related to the meaning of the line. The phrase 'mutual fear' means a feeling of fear to each other. Fear might be, for instance, in the forms of self-feeling (psyche) or a vast conflict (war). In terms of self-feeling, fear occurs of being harmed or bothered and unwilling to interfere with others' business. However, this feeling, of course, causes selfishness and carelessness toward other people's problems. In terms of war, fear occurs because each group or country has power or great weapons to avoid fighting and creating war. Nowadays, almost all countries have nuclear weapons that can damage all living things on earth, including humans. In order to avoid those worst effects, each country chooses not to release the weapon or make war. Hence, war does not happen because each country has already known other countries' power from previous war; hence they do not make war but peace. Therefore, 'mutual fear' above is caused by the previous war or a conflict between two groups or countries. 


\section{Hypocritical Humility}

Hypocritical is an adjective form of noun 'hypocrisy.' hypocrisy is an act of making yourself appears more moral than you are. However, humility is a quality of being humble (oxf.). Regarding the morphological point of view, the adjective 'hypocritical' functions as a modifier, and the noun 'humility' is the head. In other words, 'hypocritical' describes 'humility.' Hence, the phrase 'hypocritical humility' could be elaborated as a noble characteristic of humility that becomes a tool to conduct a crime or harmful acts to gain own interest. Practically, humility is no longer a humble characteristic yet a mask to cover cruelty for achieving self-benefits.

Human, according to this poem, has one last negative characteristic that is Hypocritical Humility. This characteristic or characteristic is most frequently implicitly shown in the poem. The pieces of evidence are provided in the eight-line, eleventh and twelfth line, thirteenth and fourteenth line, seventeenth and eighteenth line, and all lines in the last stanza.

And spreads his baits with care. (1. 8)

In this line, a symbol exists in the word 'care.' Generally, bait is provided with animals or foods that attract other animals to be trapped, however in this line, the bait is provided with 'care.' Actually, Blake uses 'care' as a bait in the eight lines on account of attracting the victims (innocent people) to be trapped in cruelty. Thus, 'care' symbolizes hypocrisy. In other words, the cruelty (shown by the pronoun 'his') is not practiced unreservedly but with a sly way of hypocrisy. The hypocrisy is in the form of care. The cruel human strives to show care to people with intentions to oppress them to take many benefits. Of course, innocent people will live in misery.

Then humility takes its root $(1.11)$

Underneath his foot. (1.12)

There are two figures of speech in these lines: personification and symbol. It is impossible for a characteristic of 'Humility' to have the ability to take something while it does not have hands as human. However, Blake intends to utilize the word 'Humility' to emphasize that it is not the real humble people's practice yet hypocritical people who use humility as a tool to conduct a crime. The first line above means that 'humble' people take their 'root.' 'Root' means a part of a plant that grows under the ground, absorbing water and minerals (oxf.). This word may have a symbol of the ancestor of humans who have characteristics of humility.

Moreover, in the first line, the twelfth line means that the humble people treat the ancestor unnaturally and unproperly in terms of respect by 'taking the root under their own foot.' 'Foot' is known as the lowest part of the human body, which means the lowest prestige of something or someone (oxf.). In other words, 'foot' might symbolize disparagement. Hence, the value of 'humility' here is unworthy, utilizing as a tool to conduct disparagement, cruelty, or exploitation that makes people distress, including the ancestor.

Soon spreads the dismal shade(1.13)

Of Mystery over his head;(1. 14)

A symbol is produced by a phrase of 'dismal shade of Mystery.' The phrase symbolizes hypocrisy that begins to conduct and remain a considerable number of victims due to a humble way that will not make the innocent people realize that it is a crime or cruelty. Additionally, the thirteenth line above shows that hypocrisy gives shelter to innocent people as a tool to deceive them in succeeding the evil intention, which makes people sad and hopeless in the end. Moreover, the following line means that 'the fake humility' produces hypocrisy or lies which become 'mystery' for the innocent people, 'mystery of hidden humility.'

And it bears the fruit of Deceit,(1. 17)

Ruddy and sweet to eat; (1. 18)

Similar to the previous two lines, these lines also provide a figurative speech of symbol on a phrase 'the fruit of Deceit,' and 'Ruddy and sweet.' Moreover, 'Ruddy and sweet' also produces visual and gustatory imagery. The phrase 'the fruit of Deceit' symbolizes hypocrisy, while 'Ruddy and sweet' symbolizes interesting hypocrisy through humility. Thus, these two phrases are mutually related to the practice of cruelty. Furthermore, the first line means that the tree of hypocritical humility produces the 'fruit of Deceit.' In other words, people who have hypocritical humility characteristics tend to conduct lies or hypocrisy.

Furthermore, 'the lie or hypocrisy' is beautiful, which can 'trap the preys,' trick the innocent people into succeeding in the crime 
they commit. In addition, the reader may realize that 'the fruit of Deceit' is 'Ruddy' due to a visual sense. At the same time, a taste of 'sweet' of 'the fruit' is produced by a taste or smell, included in gustatory imagery.

The Gods of the earth and sea,

Sought thro' nature to find this tree,

But their search was all in vain:

There grows one in Human Brain. (ll. 2124)

A hyperbole figure of speech is produced in these lines. The way Blake draws that the existence of hypocritical humility is on humans is exaggerated. It is proved by twenty-first to twenty-fourth lines that display even Gods cannot discover this characteristic in other creatures or things globally, but it is only found in humans. Elaborately, the highest Divine Being that conquers the earth and sea (for people who believe in) struggle for discovering the tree of hypocritical humility through the land and sea (the meaning of the twenty-first and twenty-second line), but they did not make it because the tree is only growing in the human brain (the meaning of twenty-third and twenty-fourth lines). Therefore, the lines in this stanza emphasize that hypocritical humility's characteristic genuinely only belongs to a human.

\section{Characteristics of Human Being in MurtadhaMuthahhari's Perspective}

Muthahhari classifies the positive and negative aspects of human-based on the Holy Qur'an. There are fourteen points of positive aspects and eight points of negative aspects. After conducting the analysis, it is discovered that positive human characteristics of mercy, pity, peace, and love (all at once) lie on four points of the positive aspects of humans: third, seventh, eighth, and ninth point. However, in the negative aspects of human, the negative characteristics of human (exploitation, cruelty, conflict, and hypocritical humility) are displayed in four points; the first point portrays all four negative characteristics, the second point draws exploitation, the verse in the third point displays cruelty, and the seventh point shows negative characteristics of conflict.

Murtadha Muthahhari argues that humans possess two kinds of characteristics: human and animal characteristics (Muthahhari, 2007:36). Moreover, something that makes humans different from other creatures is the human character itself which consists of iman(faith) and 'Imun' (science or knowledge). Muthahhari elaborates that it is nature that human tends to find the right ways and holy forms. In other words, the human cannot live but believe in God.

On account of 'iman' and 'ilmun' as human characteristics, the separation of both characteristics causes human prestige among other creatures. 'Iman' without 'ilmun' affects fanaticism, superstition and folly, while 'ilmun' without 'iman' is prone to abusive acts to satisfy greed, arrogance, expansionism, ambition, oppression, suppression, corruption, enslavement, deceitfulness, and deception. These negatives characteristics are related to the characteristics elaborated in The Human Abstract. A human might practice exploitation, cruelty, conflict, and hypocritical humility when their faith is less than science or nothing. This kind of human will only cause earth damage. However, when the human can balance faith and science, they can decide and act wisely. In other words, human frequently practices positive characteristics like mercy, pity, peace, and love as portrayed by William Blake in The Divine Image. As a result, the human becomes the noblest creature among others.

Muthahhari continues explaining about human perceived by Islam. In this case, Islamic education is used to improve human morals in a better direction with Islamic methods (Febriansyah, Daroini, Widowati, 2019). According to Islamic perspective, human is always related to specific histories. Human is not solely described by the highest levelanimal having big flat nails, walking with two legs and intelligent to talk. However, in Holy Qur'an, human is drawn more mystical and glorious than those words (Muthahhari, 1992:117). In the Holy Qur'an, human prestige is raised frequently yet underestimated either. They are admitted as the ones whose levels are more than heaven, earth, and even angels, but at the same time, they can be less than the devil and infernal animal. Humans are praised as creatures who can conquer the universe yet can be 'the worst of the worst.' Therefore, the human must decide their acts and destinies. 


\section{Positive Aspects of Human in Holy Qur'an}

a) Human is a caliph (successive authority) on earth (QS Al-Baqarah [2]: 30).

b) Human possesses the highest intelligence among other creatures (QS Al-Baqarah [2]: 31-33).

c) Human tends to be close to God (Allah SWT) and to do good things (QS Al-A'raaf [7]: 172 and QS Al-Ruum [30]: 43).

d) Naturally, human possesses heaven elements that do not possess by others; between real life and metaphysical, between feeling and non-feeling (material), soul and physical (QS Al-Sajdah [32]: 7-9).

e) Human is the chosen creature (QS ThaaHaa [20]: 122).

f) Human is free to choose (QS Al-Insaan [76]: 2-3).

g) Human is coronated an honor by Allah (QS Al-Israa' [17]: 70).

h) Human possesses moral consciousness that able to distinguish the right and wrong (QS Al-Syams [91]: 7-8).

i) Human soul is not peaceful before thinking about Allah, and he strives hard to be close to God (QS Al-Ra'd [13]: 28 and QS AlInsyiqaaq [84]: 6).

j) The entire creature on earth are provided for human and should be utilized in the right ways (QS Al-Baqarah [2]: 29 and QS AlJaatsiyah [45]: 13).

k) The primary responsibility of human is worshipping and obeying their God (QS AlDzaariyaat [51]: 56)

1) Humans will never recognize themselves before recognizing Allah (QS Al-Hasyr [59]: 19).

m) Humans will be shown hidden reality after he dies (QS Qaaf [50]: 22).

n) Naturally, in many cases, the human does not only case life needs, but the most is chasing God's blessing (QS Al-Fajr [89]: 2728 and QS Al-Taubah [9]: 72).

Indeed, Muthahhari does not explicitly portray human characteristics in detail as what Blake's poems do. However, the positive things of humans above already represent the human's positive characteristics, even the poems' content. For instance, the first aspect that states that humans will be caliph on earth. It means that Allah believes in humans to be caliphs for his specialty. As a result, humans can act and behave politely through all positive characteristics, including characteristics of mercy, pity, peace, and Love in The Divine Image. These four characteristics lie on the first aspect only and are discovered implicitly in the third, seventh, eighth, and ninth aspects. The third aspect shows two Holy Qur'an verses that explain about the human who believes in God so that they like to do good things including those four positive characteristics. In a verse of the seventh aspect, humans have coronated an honor by Allah that they also possess four noble characteristics. In the eight aspects, a human is noticed as a creature blessed by the moral ability to distinguish right and wrong; hence, he can also apply those four positive characteristics as the right. At last, human tends to strive hard to be close to Allah including through implementing four noble positive characteristics: mercy, pity, peace, and love.

\section{Negative Aspects of Human in Holy Qur'an}

Allah SWT does not only overestimate human in the Holy Qur'an but also underestimate them for their own mistakes (disobedient of Allah's command).

a) Human is a fool and disobedient (QS AlAhsaab [33]: 72).

b) Human is ungrateful (QS Al-Hajj [22]: 66).

c) Human transgresses (QS Al-'Alaq [96]: 6-7).

d) Human is hasty (QS Al-Israa' [17]: 11).

e) Human tends not to be thankful (QS Yunus [10]: 12).

f) Human is likely tight-fisted(QS Al-Israa' [17]: 100).

g) Human is prone to dispute (QS Al-Kahfi [18]: 54).

h) Human tends to bellyache (QS Al-Ma'aarij [70]: 19-21).

The characteristics of exploitation, cruelty, conflict, and hypocritical humility as the critical meanings in The Human Abstract also lie in some aspects above: the first, second, third, and seventh line. The verse in the first aspect explains unjust humans. In other words, this kind of human also tends to conduct exploitation, cruelty, conflict, and hypocritical humility due to an unjust trait. The second aspect, the verse means that human is ungrateful. Concerning the four negative characteristics, this verse is related to a characteristic of exploitation. Ungrateful characteristic is one of the causes of the exploitation because the one who possesses 
that trait will never feel satisfied with what he has achieved. The verse in the third aspect explains transgression, which relates to a negative characteristic of cruelty. The human who conducts cruelty is those who break the law (transgressing). The last is in the seventh aspect, which verse means that humans prone to dispute. In other words, a conflict is caused by one group and other groups who like to argue or dispute one another.

In short, the evidence of positive and negative aspects of the human through Holy Qur'an described by Muthahhari above do not indicate that human possesses two kinds of characteristics at once: both positive and negative characteristics. Holy Qur'an explains that potentially human possesses all positive characteristics and those should be practiced (Muthahhari, 2002: 220). The practice is challenging due to many obstacles to encounter. If the obstacles defeat humans, the negative traits will change them. Therefore, to lead humans in always conducting positive traits by their positive characteristics, they need iman (faith or belief). Iman to Allah produces piety that leads humans to conduct good things as practices of piety. It is proved by QS Al-'Ashr, verse 1-3: By the time, indeed, humankind is in loss, except for those who have believed and done righteous deeds and advised each other to truth and advised each other to patience. As a result, 'iman' can lead humankind to be the noblest creature among other creatures.

\section{CONCLUSION}

William Blake's The Divine Image and The Human Abstract are powerful poems in the philosophical notion that vividly portray the characteristics of a human being. It is proved by New Criticism that involves two practical analyses (paraphrasing and explication). After conducting the first analysis, The Divine Image contains positive characteristics of humans consisting of mercy, pity, peace, and love. On the other side, The Human Abstract displays the opposite human characteristics: exploitation, cruelty, conflict, and hypocritical humility.

Moreover, the enhancement of those characteristics in the poems is conducted by discovering the figure of speech and imagery. In The Divine Image, the positive characteristic of mercy is portrayed in three lines of the first poem: third, fourth, and ninth line; Pity is in the second and tenth line; Peace is in the twelfth line; Love is in the eleventh, seventeenth and eighteenth line: and all four positive characteristics (at once) are in eight lines; fifth, sixth, seventh, eighth, fifteenth, sixteenth, nineteenth, and twentieth line. Besides, in The Human Abstract, the exploitation is drawn in the first, second, and sixth line; Cruelty is in the third, fourth, seventh, ninth, tenth, nineteenth, and twentieth; Conflict is in the fifth line, and Hypocritical Humility is in eight, eleventh, twelfth, thirteenth, fourteenth, seventeenth, eighteenth, twenty-first, twenty-second, twenty-third, and twenty-fourth line.

Following the Islamic perspective, Muthahhari classifies the positive and negative aspects of humans based on the Holy Qur'an. There are fourteen points of positive aspects and eight points of negative aspects. After conducting the analysis, it is discovered that positive human characteristics of mercy, pity, peace, and love (all at once) lie on four points of the positive aspects of humans: third, seventh, eighth, and ninth point. However, in the negative aspects of human, the negative characteristics of human (exploitation, cruelty, conflict, and hypocritical humility) are displayed in four points; the first point portrays all four negative characteristics, the second point draws exploitation, the verse in the third point displays cruelty, and the seventh point shows a negative characteristic of conflict. The conclusion shows that human beings' ideas in The Divine Image and The Human Abstract relate with Islam's ideas through MurtadhaMuthahhari's thoughts.

\section{REFERENCES}

Abrams, M., Greenblatt, S., David, A., Donaldson, E., Logan, G., Smith, H., et al. (2001). The Norton Anthology of English Literature: The Major Authors / Seventh Edition / Volume B. New York: W. W. Norton \& Company. 
Amalia, Hafida. (2020). The representation of Alistair Maclean's Life as Reflected in South by Java Head: a Biographical Study. Commicast. 1(2).

Anis, RehnumaBint and Hasan, Md Mahmudul. (2020). Faith and Practice: Islamic Perspectives on Robert Browning. Intellectual Discourse. 28(1).

Arniati, Ida Ayu., Atmaja, GedeMarhaendra., and Pradana, Gede Yoga Kharisma. (2020). Moral and Religious Values in the Geguritan Dharma Prawerti Song in Bali. International Journal of Innovation, Creativity, and Change. 12(1).

Ayat - Holy Quran: KSU - Electronic Moshaf Project.

Chiles, Todd H., Crawford, Brett, and Elias, Sara RSTA. (2021). Mind, Body, and Soul: A Spiritual Perspective on the Entrepreneurial Imagination. Organization Theory. 2(2).

Douay-Rheims Version $(1609,1582)$. The Holy Bible, Translated from the Latin Vulgate, Diligently Compared with the Hebrew, Greek, and Other Editions in Divers Languages.

Eskandari, Safoura. (2020). Social and Religion Paralysis in James Joyce's Short Story The Sisters: A Cultural Reading. Budapest International Research and Critics Institute-Journal (BIRCI-Journal). 3 (1).

Febriansyah, Ferry Irawan., Daroini, Achyat., and Widowati, Widowati. 92019). The Role of Islamic Education in Student Organizations t Realize Human Resources in the Review of Higher Education Law Perspectives. Al-Hayat: Journal of Islamic Education. 3(1).

Gazalba, S. (1978). IlmuFilsafat dan Islam tentangManusia dan Agama. Jakarta: Bulan Bintang.

Halimah, Sita and Nizan, Muhammad. (2017). Character Education Values in the Novel Chant One Muara Works Ahmad Fuadi. Thesis. UIN Sumatera Timur.

Horby, A. (1995). Oxford Advanced Learner's Dictionary (5 ${ }^{\text {th }}$ ed.). Oxford: Oxford University Press.

Huda, Miftachul., Jasmi, Kamarul Azmi., Ismail, Mohd. And Basiron, Bushrah. (2017). Understanding of Wara' (Godliness) as a Feature of Character and Religious Education. The Social Science. $12(6)$

Idris, Saifullah., Tabrani, ZA., AND Sulaiman, Fikri. (2018). Critical Education Paradigm in the Perspective of Islamic Education. Advanced Science Letters. 24(11).

Kennedy, X. J., \&Gioia D. (2002). An Introduction to Poetry: Tenth Edition. New York: Longman.

Kessler, Gary E. (1999). Philosophy of Religion: Toward a Global Perspective. Canada: Wadsworth Publishing Company.

Khosravishakib, Mohammad. (2017). Social Function of Poetry from View of New Criticism. International Journal of Applied Linguistics \& English Literature.6(2).

Madiou, Mohamed Saleh Eddine. (2021). Orientalism, A Thousand and One Times: ATale of Two Perspectives. Islamic Studies. 59(3).

Manshur, F. M. (2011). Perkembangan Sastra Arab dan Teori Sastra Islam. Yogyakarta: PustakaPelajar. 
Muthahhari, M. (1992). Perspektif Al-Quran tentangManusia dan Agama. Bandung: Mizan translated and adited by Haidar Bagir et al. from some Arabic and English books of MurtadhaMuthahhari published by Free Islamic Literatures Inc., Houston, Texas.

Muthahhari, M. (2001). ManusiaSempurna: Pandangan Islam tentangHakikatManusia. Jakarta: PT. LenteraBasritama translated by M. Hashem from Perfect Man.

Muthahhari, M. (2002). Manusia dan AlamSemesta. Jakarta: PT. LenteraBasritama translated by Ilyas Hasan from Man and Universe.

Muthahhari, M. (2007). Membumikan Kitab Suci: Manusia dan Agama. Bandung: Mizan translated and edited by Haidar Bagir et al. from some Arabic and English books of MurtadhaMuthahhari published by Free Islamic Literatures Inc., Houston, Texas.

Newton, K.M. (1990). Twentieth-Century Literary Theory. Houndmills: Macmillan Education Ltd.

Nurgiyantoro, B. 2010. Sastra Anak: Pengantar Pemahaman Dunia Anak. Yogyakarta: Gadjah Mada University Press.

Oroskhan, Muhammad Hussein. (2021). Devotional Mysticism: An Analogical Study of Hafez-e Shirazi and William Blake. Theory and Practice in Language Studies. 11(5).

Pradopo, R. (2009). PengkajianPuisi. Yogyakarta: Gadjah Mada University Press.

Ramadhanti, Dina and Yanda, Diyan Permata. (2018). Understanding Poetry through the Use of Cooperative Learning Model. Cakrawala Pendidikan. 37(3).

Ratna, N. (2009). Stilistika Kajian Puitika Bahasa, Sastra, dan Budaya. Yogyakarta: Pustaka Pelajar.

Robinson, B. S. (2007). Islam and Early Modern English Literature: The Politics of Romance, From Spenser to Milton. New York: Palgrave Macmillan.

Rothman, Abdallah and oyle Adrian. (2018). Toward a Framework for Islamic Psychology Therapy: An Islamic Model of the Soul. Journal of Religion and Health. 57(5).

Salah Ameera Abed Al Hakim. (2018). Jerusalem in Poetry: A Comparative Study of the Palestina Mahmoud Darwish, The Israeli Yehuda Amichai, and the English William Blake. Thesis. Middle East University.

Sanadji, KasmiranWuryo. (1985). FilsafatManusia. Jakarta: Erlangga

Sander, David. (2020). No Riddle but Time: Historical Consciousness in two Islamicate Films. Journal of Religion and Film. 24(1).

Saraswati, Kartika Peni. (2019). Analysis of Characters and Characterization in the Compilation of Malay Poetry "Mirror). Thesis. Universitas Negeri Semarang.

Siswantoro. (2005). ApresiasiPuisi-Puisi Sastra Inggris. Surakarta: Muhammadiyah University Press.

Stewart, M. David. (2017). New Criticism and Value in Taiwanese College English. American Literature. 89 (2).

Syamsu, N. (1983). Alqurantentang Al Insan. Jakarta Timur: Ghalia Indonesia. 
Thomas, ThejasGigy, and Kumar, Prasantha. (2020). Globalization and the Sense of Home, Gender, Identity, and Religion: A Diasporic Study of Monica's Ali's Brick Lane. PalArch's Journal of Archeology of Egypt. 17(7).

Victor, Chitra G. Paul, and Treschuk, Judith. (2019). Critical Literature Review on the Definition Clarity of the Concept of Faith, Religion, and Spirituality. Journal of Holistic Nursing. 20(10).

Wainwright, J. (2004). The Basics Poetry. New York: Routledge.

Watson, G., \&Zyngier, S. (2007). Literature and Stylistics for Language Learners: Theory and Practice. New York: Palgrave Macmillan.

Webpages:

Exploitation Poverty, blame the employers. (2015). Retrieved April 25, 2015, from http://worldpoverty.org/exploitationpoverty.htm

http://dictionary.reference.com/browse

Raven in Mythology. (1998). Retrieved April 25, 2015, from http://ravenfamily.org/nascakiyetl/obs/rav1.html

Paraphrasing and Summarizing. (n.d.). Retrieved April 25, 2015, from https://web.cn.edu/kwheeler/documents/paraphrase.pdf 